\title{
PENDUGAAN DAYA DUKUNG PERAIRAN TELUK AWARANGE BAGI PENGEMBANGAN BUDI DAYA BANDENG DALAM KERAMBA JARING APUNG
}

\author{
Rachmansyah, Makmur, dan Tarunamulia
}

\begin{abstract}
ABSTRAK
Daya dukung memiliki peran penting dalam pengambilan keputusan pengelolaan sumber daya perikanan budi daya. Metode survai dilakukan dalam studi ini untuk mengevaluasi kualitas biofisik Teluk Awarange (Sulawesi Selatan) dan untuk menentukan kelayakan Iahan bagi pengembangan budi daya bandeng dalam keramba jaring apung (KJA). Pendugaan daya dukung mengacu pada ketersediaan oksigen terlarut, laju konsumsi oksigen bandeng, dan beban limbah total fosfat baik yang bersumber dari kegiatan budi daya bandeng dalam KJA maupun kegiatan non-budidaya ikan dalam KJA. Nilai daya dukung yang diperoleh diverifikasi dengan pendugaan keseimbangan oksigen terlarut perairan T. Awarange, produksi ikan maksimum tahunan per unit area, kapasitas lingkungan mengabsorbsi beban nutrien, dan kedalaman minimum kolom air di bawah keramba. T. Awarange memiliki luas lahan yang layak untuk perikanan budi daya dengan sistem KJA seluas 28 ha dengan daya dukung biomassa ikan sebesar 36 ton. Produksi maksimum tahunan yang diperkenankan antara 1,3-1,6 $\mathrm{t} \mathrm{ha}^{-1}$, di mana kapasitas lingkungan untuk mengabsorbsi beban nutrien pada konsentrasi maksimum yang diperkenankan masing-masing sebesar 6,762 ton TN $(0,35 \mathrm{mg} / \mathrm{L})$ dan 3,077 ton TP $(0,06 \mathrm{mg} / \mathrm{L})$. Kedalaman minimum kolom air di bawah KJA adalah $>8 \mathrm{~m}$ untuk meminimasi dampak bentik yang dapat digunakan sebagai acuan untuk pedoman di dalam pemilihan lokasi KJA. Jika diasumsikan ukuran keramba adalah $8 \mathrm{~m}^{3}$ dengan tingkat produktivitas 0,25 ton per keramba, maka total maksimum keramba yang boleh dioperasionalkan di T. Awarange adalah <144 keramba
\end{abstract}

\begin{abstract}
Carrying capacity assessment of Awarange Bay for milkfish culture development in floating net cages. By: Rachmansyah, Makmur, and Tarunamulia
\end{abstract}

Carrying capacity is the most important role in improving the quality of management decisionmaking of resources allocation on marine fish farming. Survey method was used in this study to evaluate the biophysical quality of Awarange Bay (South Sulawasi) and to determine the suitable area for milkfish marine farming development. Carrying capacity prediction based on dissolved oxygen availability, oxygen consumption rate of milkfish, and total waste load of phosphor which enter the bay both from the fish cages and from other activities surrounding the bay. Prediction of carrying capacity will be verified with balance of dissolved oxygen prediction of Awarange Bay, maximum allowable annual fish production per unit area, capacity of the environment to absorb the loading nutrient, and minimum sitting depth of milkfish cages. Awarange Bay has potential area of marine fish farming about 28 ha which has carrying capacity of fish biomass about 36 ton. The maximum annual fish production are ranging from 1.3 to $1.6 \mathrm{t} / \mathrm{ha}$, while capacity of the environment to absorb load nutrient both total nitrogen and total phosphor is about 6.762 ton TN and 3.077 ton TP respectively. The sitting depth of milkfish cages is more than $8 \mathrm{~m}$ to minimize benthic impacts that have actually been used for regulating marine farming sites. If the assumption of individual cages size is $8 \mathrm{~m}^{3}$ and has productivity of 0,25 t/cage, the total maximun allowable number of cages to operate in Awarange Bay is less than 144 units.

KEYWORDS: $\quad$ management, milkfish, marine fish farming, sustainability, Awarange Bay

\section{PENDAHULUAN}

Daya dukung merupakan populasi organisme akuatik yang akan ditunjang oleh suatu kawasan atau areal atau volume perairan yang ditentukan tanpa mengalami penurunan mutu atau deteriorasi (Turner,
1988). Kenchington \& Hudson (1984) mendefinisikan daya dukung sebagai kuantitas maksimum ikan yang dapat didukung oleh suatu badan air selama jangka waktu panjang. Definisi lain menyebutkan daya dukung adalah batasan untuk banyaknya organisme hidup dalam jumlah atau massa yang dapat didukung oleh

Peneliti pada Balai Riset Perikanan Budidaya Air Payau, Maros 
suatu habitat. Jadi daya dukung adalah ultimate constraint yang diperhadapkan pada biota oleh adanya keterbatasan lingkungan seperti ketersediaan makanan, ruang atau tempat berpijah, penyakit, siklus predator, temperatur, cahaya matahari, atau salinitas. Karenanya, daya dukung kawasan pada akhirnya akan menentukan kelangkaan sumber daya alam vital dan jasa lingkungan yang dibutuhkan oleh manusia dan organisme hidup yang mendiami kawasan tersebut (Dahuri, 2002). Jadi daya dukung lingkungan dapat berkurang akibat kerusakan yang ditimbulkan oleh manusia yang mengurangi ketersediaan suplai energi atau penggunaan energi (Clark, 1974). Daya dukung lingkungan sangat erat kaitannya dengan kapasitas asimilasi dari lingkungan yang menggambarkan jumlah limbah yang dapat dibuang ke dalam lingkungan tanpa menyebabkan polusi (UNEP, 1993).

Piper et al. (1982) dalam Meade (1989), mendefinisikan daya dukung sebagai suatu sistem yang dapat mendukung beban hewan yang dinyatakan sebagai bobot ikan per kaki kubik air $\left(\mathrm{lb} / \mathrm{ft}^{3}\right)$. Haskell (1995) dalam Meade (1989) membuat dua asumsi yang menyangkut daya dukung, yaitu (1) dibatasi oleh laju konsumsi oksigen dan akumulasi metabolit, dan (2) laju tersebut sebanding dengan jumlah pakan yang dimakan per hari. Inglis et al. (2000) dalam Anonymous (2002) menyajikan empat interpretasi penting tentang daya dukung yaitu (1) daya dukung fisik yang terkait dengan batasan tempat terhadap ukuran dan jumlah unit budi daya yang dipengaruhi oleh faktor geografis, perencanaan, dan infrastruktur; (2) daya dukung sosial terkait dengan dampak yang tidak dapat diterima secara sosial seperti pengurangan visual amenity dan akses; (3) daya dukung produksi didefinisikan sebagai kepadatan stok yang dapat dipanen maksimal secara berkelanjutan; dan (4) daya dukung ekologi didefinisikan sebagai jumlah unit budi daya yang dikembangkan tanpa menimbulkan dampak ekologi. Berdasarkan batasan daya dukung yang ada nampak bahwa definisi baku daya dukung belum ada, namun lebih ditekankan pada masalah yang menjadi tujuan studi. Dalam penelitian ini daya dukung didefinisikan sebagai kapasitas suatu lingkungan perairan untuk mendukung sejumlah bobot biomassa ikan yang dapat hidup dan tumbuh secara optimal berkelanjutan dalam suatu lingkungan perairan yang telah ditetapkan memenuhi persyaratan biotekno-sosio-ekonomi dan legal bagi kegiatan budi daya. Karena itu, potensi lahan dan kondisi biofisik lingkungan perairan serta beban limbah yang masuk ke dalam sistem perairan tersebut menjadi peubah penentu penduga daya dukung

Salah satu faktor kritis yang menentukan daya dukung perairan pesisir adalah ketersediaan oksigen terlarut (SE, 2002). Cholik et al. (1990) mendapatkan konsentrasi oksigen terlarut dalam keramba nila merah di laut dengan kepadatan 750 ekor $\mathrm{m}^{-3}$ mencapai 1,5$2,0 \mathrm{mg} / \mathrm{L}$ pada malam hari sampai menjelang pagi hari pada pemeliharaan bulan ke-3, sementara di keramba jaring apung (KJA) bandeng terjadi pada kepadatan 150 ekor $\mathrm{m}^{3}$ (Pongsapan et al., 2001). Kondisi hypoxia ini oleh Schmittou (1991) disebut sebagai low dissolved oxygen syndrome (LODOS), kondisi di mana kelarutan oksigen rendah yang diikuti secara simultan oleh meningkatnya karbondioksida, penurunan $\mathrm{pH}$ air, meningkatnya asam laktat darah dan menurunnya $\mathrm{pH}$ darah ikan, meningkatnya amonia dan nitrit serta sejumlah faktor lainnya. Karena itu pengurangan oksigen terlarut merupakan faktor pembatas utama dan menjadi perhatian serius dalam operasi budi daya ikan (McLean et al., 1993). Kondisi hypoxia suatu perairan merupakan gejala tekanan lingkungan perairan untuk budi daya sekaligus sebagai faktor pembatas daya dukung.

Oksigen dipasok dari permukaan air dan transpor melalui kolom air oleh difusi dan turbulensi serta melalui hasil proses fotosintesis. Pada malam hari, aktivitas hewan, tanaman, dan bakteria di dalam kolom air dan sedimen akan mengkonsumsi oksigen melalui proses respirasi. Jika proses respirasi memerlukan pasokan oksigen yang berlebih maka ketersediaan oksigen terlarut akan berkurang, bahkan ketersediaan oksigen akan mempengaruhi kehidupan ikan dan organisme perairan lainnya. Kosentrasi minimum oksigen terlarut digunakan untuk menduga laju beban maksimum yang dibolehkan atau daya dukung (McLean et al., 1993). Kebutuhan oksigen juga dikontrol oleh laju pasokan bahan organik. Nutrien diduga mempengaruhi pasokan oksigen melalui stimulasi produktivitas primer yang pada akhirnya akan kembali dikonsumsi oleh bakteri dan hewan. Karena itu, ketersediaan oksigen terlarut dan beban nutrien akan menentukan daya dukung dari suatu perairan

Kebutuhan informasi perikanan budi daya menyangkut distribusi spasial lokasi pengembangan budi daya yang dilengkapi dengan informasi daya dukung lingkungan perairan berperan penting dalam memformulasi kebijakan pengelolaan perikanan budi daya. Penelitian ini bertujuan mendapatkan informasi daya dukung T. Awarange (Sulawesi Selatan) untuk kawasan pengembangan budi daya perikanan. Karena itu, hasil penelitian ini diharapkan dapat menjadi sumber informasi yang dibutuhkan serta panduan dalam perencanaan pengelolaan dan pengembangan budi daya ikan dalam KJA di T. Awarange yang berkelanjutan.

\section{METODE PENELITIAN}

Terdapat tiga pendekatan dalam menentukan daya dukung lingkungan bagi pengembangan budi daya 
bandeng dalam KJA di laut, yaitu pendekatan mengacu pada (1) beban limbah total fosfor (TP) dari sistem budi daya yang terbuang ke lingkungan perairan; (2) kapasitas ketersediaan oksigen terlarut dalam badan air serta laju konsumsi oksigen ikan bandeng; dan (3) kapasitas ketersediaan oksigen terlarut dan food consumption oxygen

Metode 1. Pendugaan daya dukung lingkungan perairan untuk budi daya bandeng di laut mengacu pada tahapan yang dikemukakan oleh Beveridge (1984; 1996) sebagai berikut: menghitung luasan permukaan dari badan air (A-ha), rataan kedalaman Z $=\mathrm{V} / \mathrm{A}$ meter (dihitung dari survai oseanografi dan peta bathymetri), di mana $\mathrm{V}$ adalah volume badan air $\left(\mathrm{m}^{3}\right)$, dan Flushing koefisien $\mathrm{r} \mathrm{th}^{-1}$ (ditentukan dari sampling outflow pasang surut), dihitung berdasarkan formula yang dikemukakan oleh Gowen et al. (1989) dalam Barg (1992), sebagai berikut: $D=(V h-V I) / T \times V h$; di mana $(\mathrm{Vh}-\mathrm{Vl})$ adalah volume pergantian setiap pasang; $\mathrm{Vh}=$ volume air dari badan air saat pasang $\left(\mathrm{m}^{3}\right) ; \mathrm{VI}=$ volume air badan air saat surut $\left(\mathrm{m}^{3}\right) ; \mathrm{T}=$ periode pasang (hari). Flushing koefisien $(F=1 / D)$. Dari data di atas maka daya dukung lingkungan perairan dapat ditentukan dengan tahapan sebagai berikut:

Tahap 1. Mengukur steady state $[\mathrm{P}]_{\mathrm{i}}$ dari konsentrasi total-P, yang ditentukan berdasarkan rataan tahunan konsentrasi total-P dalam badan air, diperoleh dari sejumlah sampel yang representatif selama satu tahun, dimisalkan adalah $\mathrm{P} \mathrm{mg} \mathrm{m}^{-3}$

Tahap 2. Menentukan [P] maksimum yang dapat diterima oleh badan air $[\mathrm{P}]_{\mathrm{f}}$ akibat adanya budi daya bandeng dalam KJA

Tahap 3. Menentukan kapasitas badan air untuk budi daya bandeng secara intensif $D[P]$, yaitu selisih antara $[P]$ sebelum dimanfaatkan untuk budi daya $[\mathrm{P}]_{\mathrm{i}}$ dengan $[\mathrm{P}]$ maksimum yang dapat diterima $[P]_{f}$ setelah keberadaan keramba bandeng, sehingga $D[P]=[P]_{f}-[P] i$ Oleh karena $D[P]$, berhubungan dengan beban $P$ dari keramba bandeng yaitu $L_{\text {fish' }}$ luasan badan air $(A)$, laju pembilasan dan kemampuan badan air untuk menangani loading $\mathrm{P}$, maka: $\mathrm{D}[\mathrm{P}]=\mathrm{L}_{\text {fish }}\left(1-\mathrm{R}_{\text {fish }}\right) / \mathrm{Zr}$,

$$
\begin{aligned}
& L_{\text {fish }}=D[P]^{*} Z^{*} r / 1-R_{\text {fish }} \\
& \mathrm{R}_{\text {fish }}=x+[(1-x) R] \text {; di mana } R=1 /(1+ \\
& \left.r^{0.5}\right)
\end{aligned}
$$

$D[P]$ adalah total- $P\left(\mathrm{~g} \mathrm{~m}^{-3}\right)$; $\mathrm{L}_{\text {fish }}$ (total- $\mathrm{P} \mathrm{g} \mathrm{m}$. ${ }^{2}$ th $^{-1}$ ); $Z$ (rataan kedalaman badan air dalam meter); $r$ adalah flushing koefisien; $\mathrm{R}_{\text {fish }}$ (total-P yang larut ke dalam sedimen); $x$ (total$P$ yang hilang secara permanen ke dalam sedimen)

Tahap 4. Jika telah diketahui luasan badan air $\left(\mathrm{A} \mathrm{m}^{2}\right)$, beban total- $\mathrm{P}$ yang dapat diterima $\left(\mathrm{L}_{\mathrm{fish}} \mathrm{kg}\right.$ th $\left.^{-1}\right)$, beban total-P yang hilang ke lingkungan selama budi daya ( $\mathrm{kg}-\mathrm{P} / \mathrm{ton}$ ikan), maka dapat dihitung jumlah ikan (ton th-1) yang dapat diproduksi, yaitu: $L_{\text {fish }} \times A /$ total- $P$

Nilai kapasitas produksi ini akan digunakan sebagai petunjuk awal dalam menentukan daya dukung badan air untuk produksi bandeng dalam KJA.

Metode 2. Penentuan daya dukung berdasarkan kapasitas ketersediaan kandungan oksigen terlarut dari badan air, dimodifikasi dengan mengacu pada formula yang dikemukakan oleh Willoughby (1968) dalam Meade (1989); Boyd (1990). Pergantian air akibat pasang surut akan menyediakan atau memasok oksigen sehingga konsumsi oksigen oleh organisme non budi daya diasumsikan tidak signifikan. Hal ini berarti bahwa perairan pesisir dapat dibebani dengan sejumlah ikan yang menggunakan oksigen terlarut, di mana $\mathrm{O}_{2}$ dipasok baik yang berasal dari aliran air pasang surut maupun difusi dari udara.

Tahap 1. Menentukan ketersediaan oksigen terlarut dalam badan air adalah perbedaan antara konsentrasi $\mathrm{O}_{2}$ terlarut di dalam inflow $\left(\mathrm{O}_{\text {in }}\right)$ dan konsentrasi $\mathrm{O}_{2}$ terlarut minimal yang dikehendaki dari sistem budi daya $\left(\mathrm{O}_{\text {out }}\right)$ yaitu 4 mg/L (Boyd, 1990; Lee et al., 2001). Jika dimisalkan debit air inflow diketahui Qo $\mathrm{m}^{3} / \mathrm{min}$, maka total $\mathrm{O}_{2}$ terlarut selama periode 24 jam adalah:

$$
\text { Qo } \mathrm{m}^{3} / \mathrm{min} \times 1.440 \mathrm{~min} / \text { hari } \times\left(\mathrm{O}_{\text {in }}-\mathrm{O}_{\text {out }}\right)
$$$$
\mathrm{gO}_{2} / \mathrm{m}^{3}=\mathrm{X} \mathrm{kg} \mathrm{O}_{2}
$$

Tahap 2. Jika laju konsumsi oksigen ikan (Ro) diketahui, maka daya dukung maksimal yang diijinkan ( $\mathrm{kg}$ ikan) dapat dihitung yaitu $\mathrm{X} \mathrm{kgO}_{2} / \mathrm{Ro} \mathrm{kgO}$ per kg ikan.

Metode 3 . Pendekatan melalui kapasitas ketersediaan oksigen terlarut dan food cunsumption oxygen, di mana:

Tahap 1 dan 2 sama dengan metode 2

Tahap 3. Umumnya pendugaan standing crop yang diijinkan dengan mengacu bahwa untuk setiap kilogram pakan membutuhkan $0,2 \mathrm{~kg}$ $\mathrm{O}_{2}$ sehingga dapat diduga laju pemberian pakan harian maksimal yang diizinkan. Dengan demikian, laju pemberian pakan harian maksimal tidak boleh melebihi ketersediaan $\mathrm{O}_{2}$ terlarut $\left(\mathrm{X} \mathrm{kg} \mathrm{O}_{2}\right)$. Jadi jumlah pakan maksimal harian adalah kapasitas $\mathrm{O}_{2}$ terlarut $\mathrm{kg} / 0,2 \mathrm{~kg} \mathrm{O} / \mathrm{kg}$ pakan $=\mathrm{Y} \mathrm{kg}$ pakan. Jika diketahui persentase pemberian pakan $=Z \%$, maka daya dukung lingkungan perairan untuk budi daya bandeng adalah: Daya dukung ( $\mathrm{kg}$ ikan) = jumlah pakan maksimal harian ( $Y$ kg pakan)/Z. 
Hasil perhitungan daya dukung di atas kemudian diverifikasi dengan pendugaan kapasitas asimilasi, pendekatan keseimbangan oksigen terlarut, produksi maksimum tahunan, dan kedalaman minimal keramba (Silvert, 1992) sebagai acuan pengelolaan budi daya ikan dalam KJA di T. Awarange yang berwawasan lingkungan.

Pendugaan produksi maksimum tahunan dihitung dengan formula Silvert (1992) sebagai berikut:

Kebijakan pengelolaan budi daya ikan dalam KJA dapat juga dikembangkan dengan model yang didesain untuk mengontrol beban limbah organik, namun model ini sangat sulit membedakan antara partikel organik lebih besar yang mengendap lebih cepat dan partikel organik halus serta partikel organik terlarut yang berada di dalam kolom air. Jika parameter flushing dimasukkan ke dalam perhitungan, maka nampak lebih beralasan untuk mengasumsikan bahwa pendekatan beban suspensi organik dan organik terlarut menjadi lebih berarti. Dengan memasukkan parameter faktor beban limbah organik $(\mathrm{g})$ terhadap produksi tahunan $(Y)$, level kritis beban limbah organik yang dapat ditoleransi (Ccrit), dan kedalaman badan air (Z), maka produksi maksimum tahunan yang aman per unit area (Maximum safe annual production per unit area) dapat dihitung mengacu pada Silvert (1992) dengan persamaan:

$$
Y / A=Z C_{(r n} / \gamma \cdot T
$$

di mana:

$\mathrm{Y}=$ produksi tahunan (ton)

$A=$ luas perairan (28 ha)

$Z=$ kedalaman perairan $=9,673 \mathrm{~m}$

$C_{\text {crit }}=$ level kritis beban limbah oraganik $\left(80 \mathrm{~g} / \mathrm{m}^{3}\right.$ diambil dari nilai TSS yang direkomendasikan Wedemeyer (1996)

$g=$ proporsi beban limbah organik terhadap produksi tahunan $(0,15)$

$\mathrm{T}=$ flushing time (15 hari)

\section{Pendugaan Kedalaman Minimal di Bawah Keramba}

Pendugaan kedalaman kolom air minimal di bawah keramba bertujuan untuk menyediakan informasi tentang upaya minimasi dampak benthik akibat beroperasinya KJA. Kedalaman kolom air minimal diharapkan dapat memberikan peluang sebagai media pelarut beban limbah budi daya pada batas kapasitas asimilasi perairan. Informasi ini diperlukan untuk pengelolaan unit KJA yang biasanya hanya mengacu pada petunjuk praktis (rules of thumb) yang didasari atas informasi ilmiah yang lemah. Untuk meminimasi dampak lokal dari KJA maka Silvert (1992) mengemukakan model kedalaman peletakan keramba minimum dari dasar perairan sebagai berikut:

$$
Z_{\text {min }}=\sqrt{\frac{P Y}{(V+\eta)}}
$$

di mana: $P=\frac{S^{2} \cdot p}{4 \cdot B \cdot \eta}$

$P=$ rasio antara output partikel bahan organik terhadap produksi $(0,15)$

$\mathrm{S}=$ kecepatan pengendapan $0,0226 \mathrm{~m} \mathrm{~s}$ (Kamaruddin \& Rachmansyah, 2003)

$B=$ kapasitas asimilasi $\left(0,125 \mathrm{~g} \mathrm{~m}^{2} \mathrm{hr}^{-1}\right), Y=1 /(0,0099$ $+0,002^{\star} T^{1,1689}$

$Y=1$, jika $T=200$ hari (Rachmansyah et al., 2003c)

$\mathrm{h}=$ koefisien difusi horizontal $=0,1 \mathrm{~m}^{2} \mathrm{~s}^{-1}$ (Gillibrand et al., 2002)

$Y=$ produksi tahunan (36 ton $\times 2$ musim pemeliharaan $=72$ ton)

$V=$ kecepatan arus rataan $T$. Awarange $\left(0,058 \mathrm{~m} \mathrm{~s}^{-1}\right)$

\section{HASIL DAN BAHASAN}

Pendugaan daya dukung lingkungan perairan $T$. Awarange bagi pengembangan budi daya bandeng dalam KJA mengacu pada data kondisi karakteristik biofisik dan kelayakan bioteknis T. Awarange bagi budi daya bandeng dalam KJA (Rachmansyah et al., 2002b), data keragaan budi daya bandeng dan beban limbah dari KJA bandeng (Rachmansyah et al., 2003), laju konsumsi oksigen dan level kritis oksigen bandeng (Rachmansyah et al., 2002d), beban limbah P yang bersumber dari aktivitas non-KJA (Rachmansyah \& Usman, 2003), dan beberapa parameter yang bersumber dari pustaka terkait dengan studi ini. Parameter yang menjadi acuan untuk menduga daya dukung adalah:

a. Luas teluk $=5.644 .410 \mathrm{~m}^{2}$ atau 564,441 ha pada kondisi Mean Sea Level (MSL)

b. Luas lahan yang layak untuk budi daya $\mathrm{KJA}=28$ ha ditetapkan sebagai unit pengembangan kawasan budi daya (UPKB)

c. Rataan kedalaman teluk $=9,673 \mathrm{~m}$

d. Volume air pasang surut ( $V$ pasut): $3.592 .000 \mathrm{~m}^{3}$

e. Flushing time $=15$ hari

f. Rataan konsentrasi oksigen terlarut dalam kondisi steady state $=6 \mathrm{mg} / \mathrm{L}$

g. Konsentrasi oksigen terlarut minimal yang dibutuhkan dalam sistem budi daya ( $\mathrm{C} \mathrm{O}_{2}$ out): 4 $\mathrm{mg} / \mathrm{L}$ diambil dari level kritis oksigen (Rachmansyah et al., 2002d); Lee et al. (2001); dan Wedemeyer (1996).

h. Laju konsumsi bandeng (Ro) $=384,60 \mathrm{mg} \mathrm{kg}^{-1} \mathrm{jam}^{-}$ 
${ }^{1}$ (Rachmansyah et al., 2002d)

i. Food consumption oxygen $0,2 \mathrm{~kg} \mathrm{O}_{2}$ per $\mathrm{kg}$ pakan (Willoughby, 1968 dalam Meade, 1989; Boyd, 1990).

j. Persentase pemberian pakan rataan $5 \%$ bobot bandeng

k. Steady state $\mathrm{P}$ dari hasil monitoring $=32 \mathrm{mg} \mathrm{m}^{-3}$

I. Maximum Acceptable $\mathrm{P}=60 \mathrm{mg} \mathrm{m}^{3}$ (Beveridge, 1996)

m. Total beban P per ton ikan $=30,87 \mathrm{~kg}$ per ton produksi ikan (Rachmansyah et al., 2003)

n. Total beban $P$ dari aktivitas non $\mathrm{KJA}=236,207 \mathrm{~kg}$ th-1 (Rachmansyah \& Usman, 2003)

o. Produktivitas bandeng $=250 \mathrm{~kg}$ per keramba (Rachmansyah et al., 2002a)

Dari ketiga metode pendekatan yang digunakan dalam pendugaan daya dukung lingkungan perairan bagi pengembangan KJA bandeng diperoleh kisaran antara 33-39 ton dengan nilai rataan $36 \pm 3$ ton untuk UPKB seluas 28 ha, sedangkan T. Awarange sebagai entitas ekologi memiliki daya dukung potensial sebesar $724 \pm 51$ ton (Tabel 1). Ketiga pendekatan tersebut menghasilkan koefisien variasi $<10 \%$ sehingga ketiga metode pendekatan tersebut dapat digunakan sebagai penduga daya dukung lingkungan perairan bagi budi daya bandeng dalam KJA di T. Awarange.

Teluk Awarange juga berfungsi sebagai pelabuhan antar pulau, daerah penangkapan perikanan artisanal, alur pelayaran dan pendaratan kapal ikan, sumber pasok air bagi pertambakan, hatcheri, dan aktivitas ekonomi di sekitar teluk. Berdasarkan status pemanfaatannya, maka dalam menentukan daya dukung perairan untuk KJA perlu mengacu pada persyaratan kelayakan bioteknis untuk lahan budi daya. Hasil analisis kelayakan lahan sebelumnya, diperoleh luas perairan yang layak untuk UPKB adalah 28 ha dengan rataan kedalaman perairan 9,67 m (Rachmansyah et al., 2002b). Perhitungan daya dukung difokuskan pada UPKB Teluk Awarange yang dianggap sebagai daya dukung riil untuk pengembangan budi daya bandeng dalam KJA yaitu 36 ton. Berdasarkan asumsi yang digunakan, maka jumlah rakit dan keramba yang boleh dioperasionalkan masing-masing sebanyak 15 unit dan 144 keramba atau sekitar $5 \%$ dari potensi daya dukung Teluk Awarange 724 ton atau sekitar $5 \%$ (28 ha) dari luas Teluk Awarange 564,41 ha pada kondisi MSL.

Lee et al. (2001) melakukan pendugaan daya dukung lingkungan perairan di Hongkong melalui pendekatan kualitas air meliputi klorofil-a, oksigen terlarut, nitrogen organik, dan potensi level oksigen kritis (LOK) dengan mengabaikan produksi fotosintesis. Dijelaskan bahwa daya dukung tergantung pada laju pembasuhan (flushing rate), beban polutan, kedalaman air dan volume budi daya ikan. Potensi terendah oksigen terlarut dapat diakibatkan oleh kombinasi laju pembasuhan yang rendah dan tingginya beban organik. Metode pendekatan yang digunakan dalam penelitian ini relatif sama dengan metode Lee et al. (2001), di mana parameter penduga daya dukung yang digunakan dapat memberikan gambaran kondisi daya dukung perairan Teluk Awarange bagi pengembangan budi daya bandeng dalam KJA yang bertanggung jawab.

Tabel 1. Daya dukung Teluk Awarange untuk pengembangan KJA bandeng

Table 1. Carrying capacity of Awarange Bay for milkfish cage farming development

\begin{tabular}{|c|c|c|}
\hline \multirow{2}{*}{$\begin{array}{l}\text { Metode pendekatan } \\
\text { Approach methods }\end{array}$} & \multicolumn{2}{|c|}{$\begin{array}{l}\text { Daya dukung untuk budi daya bandeng } \\
\text { Carrying capacity of milkfish cage farming }\end{array}$} \\
\hline & $\begin{array}{l}\text { UPKB } \\
C Z D U\end{array}$ & $\begin{array}{c}\text { Teluk Awarange } \\
\text { Awarange Bay }\end{array}$ \\
\hline $\begin{array}{l}\text { Total beban limah } P \text { yang dapat diterima } \\
\text { Total acceptable loading } P\end{array}$ & 33 & 676 \\
\hline $\begin{array}{l}\text { Kapasitas ketersediaan oksigen terlarut dalam perairan } \\
\text { dan laju konsumsi oksigen bandeng } \\
\text { Dissolved oxygen availability and oxygen consumption } \\
\text { rate of milkfish }\end{array}$ & 39 & 778 \\
\hline $\begin{array}{l}\text { Kapasitas ketersediaan oksigen terlarut dalam perairan } \\
\text { dan jumlah pakan maksimal yang digunakan } \\
\text { Dissolved oxygen availability and maximum feed intake }\end{array}$ & 36 & 718 \\
\hline $\begin{array}{l}\text { Rataan daya dukung untuk budi daya bandeng dalam KJA } \\
\text { Average of carrying capacity for milkfish cage culture }\end{array}$ & $36 \pm 3$ & $724 \pm 51$ \\
\hline
\end{tabular}

Keterangan:UPKB (unit pengembangan kawasan budi daya)

Note:CZDU (Culture zone development unit) 
Pillay (1992) menyebutkan batasan produksi ikan sebesar $110 \mathrm{t} \mathrm{km}^{-2}$ atau 1,1 ton ha-1 pada kondisi perairan dengan kecepatan arus minimum $5 \mathrm{~cm} \mathrm{~s}^{-1}$ dan kedalaman minimum kolom air di bawah keramba sampai dasar perairan adalah $4 \mathrm{~m}$ untuk memberikan peluang yang cukup bagi proses pelarutan dan distribusi limbah. Barker et al. (2002) menyebutkan kepadatan ikan optimum di dalam keramba adalah $20 \mathrm{~kg} \mathrm{~m}^{-3}$ tergantung pada kualitas air, ukuran ikan, temperatur dan pasokan oksigen, sedangkan kepadatan maksimum dapat mencapai $100 \mathrm{~kg} \mathrm{~m}^{-3}$ namun lebih membutuhkan pengontrolan kualitas air, pengalaman budi daya yang banyak, dan risiko yang lebih tinggi. Hasil penelitian Burhanuddin et al. (1994) menyebutkan tingkat produktivitas bandeng dalam KJA yang dipelihara di muara Sungai Minasatene, Barru, Sulawesi Selatan mencapai $102,87 \mathrm{~kg} \mathrm{~m}^{-3}$ dan $124,66 \mathrm{~kg} \mathrm{~m}^{-3}$ masing-masing pada kepadatan ikan 400 dan 500 ekor $\mathrm{m}^{-3}$ dengan rataan bobot individu antara 265,94-267,15 g/ekor. Diduga kondisi arus yang cukup di muara sungai tersebut berperan dalam memasok kebutuhan oksigen bagi kehidupan ikan sekaligus membuang beban limbah yang berasal dari KJA bandeng, sehingga kepadatan ikan yang dapat didukung oleh perairan tersebut cukup tinggi mencapai 500 ekor $\mathrm{m}^{-3}$ setara dengan $125 \mathrm{~kg}$ ikan $\mathrm{m}^{-3}$

Di Norwegia, regulasi budi daya ikan dalam KJA diatur berdasarkan volume air. Sebagian besar pembudi daya memiliki ijin budi daya seluas 12.000 $\mathrm{m}^{3}$ dengan batasan $25 \mathrm{~kg} \mathrm{~m}^{-3}$. Volume air dihitung dari $85 \%$ luas keramba dikalikan dengan kedalaman air $5 \mathrm{~m}$. Karena itu, biomassa maksimum sekitar 300 ton ikan (Jahnsen, www.mar.dfo-mpo.gc.ca/science/ mesd/he/eim/report.html-63k).

Mengacu pada pendapat di atas, maka kapasitas produksi ikan dalam KJA di Teluk Awarange sebesar $31,25 \mathrm{~kg} \mathrm{~m}^{-3}$ atau 36 ton utuk luasan lahan 28 ha $\left(1,28 \mathrm{t} \mathrm{ha}^{-1}\right)$, berada pada kisaran yang telah menjadi panduan umum dan hasil penelitian sebelumnya (Tabel 2). Jadi penentuan kepadatan ikan per unit keramba menjadi spesifik lokasi tergantung pada kondisi biofisik perairan setempat.

Pengaturan pemberian ijin operasional budi daya ikan dalam KJA di Teluk Awarange harus mengacu pada kondisi daya dukung perairan, luas perairan yang layak, dan tingkat produktivitas ikan yang dapat dicapai. Dengan demikian jumlah keramba yang diperbolehkan adalah sebanyak 144 keramba (@8 $\mathrm{m}^{3}$ ) dengan kepadatan ikan 62 ekor $\mathrm{m}^{-3}$. Salah satu pembatasan terhadap kepadatan ikan budi daya adalah spesifikasi minimum ruang gerak untuk menghindari peluang transmisi penyakit antar unit budi daya dalam beberapa ratus meter (Silvert \& Sowles, 1996). Meskipun hal ini digunakan secara luas untuk mengatur pembatasan unit usaha, namun nampak kurang didasarkan atas informasi tentang berapa jarak minimum spesifik yang dapat diaplikasikan.

Masalah lain yang menjadi pertimbangan adalah (1) bagaimana beban limbah nutrien dari KJA dapat mempengaruhi produktivitas primer, khususnya peledakan populasi alga beracun, dan (2) bagaimana peningkatan nutrien akan mempengaruhi komunitas plankton tetapi perubahan nutrien dapat diketahui. Dengan mengkombinasikan beban limbah budi daya dan batasan maksimum level nutrien yang direkomendasikan untuk kehidupan ikan budi daya, maka pendugaan kapasitas asimilasi menjadi penting dilakukan

Alokasi input produksi melebihi daya dukung lingkungan akan berdampak pada penurunan kualitas lingkungan perairan yang pada gilirannya dapat mempengaruhi keberlanjutan budi daya itu sendiri. Karena itu, budi daya ikan laut yang berkelanjutan membutuhkan input nutrien pada level yang tidak melebihi daya dukung lingkungan budi daya. Limbah budi daya akan memiliki dampak negatif yang kecil terhadap lingkungan manakala lokasi budi daya tersebut berada di wilayah yang terbuka, memiliki laju pembasuhan yang baik, dan percampuran massa air yang sempurna (Pettigrew, www.fobhb.org/ pettigrew.htm). Dengan demikian, total input nutrien yang berasal dari limbah budi daya dan sumber lain non budi daya seperti run-off dari lahan pertanian tidak boleh mengakibatkan peningkatan pengkayaan nutrien, blooming produksi fitoplankton dan merubah komposisi spesies yang pada gilirannya dapat berdampak pada keberlanjutan usaha budi daya itu sendiri.

\section{Pendugaan Daya Dukung Melalui Kapasitas Asimilasi}

Pendugaan kapasitas asimilasi didasarkan atas kriteria untuk kondisi perairan laut mesotrophic yaitu total nitrogen (TN) $0,350 \mathrm{mg} \mathrm{L}^{-1}$ (Smith et al., 1999) dan total fosfor (TP) yang diperkenankan setelah ada kegiatan budi daya yaitu $0,060 \mathrm{mg} \mathrm{L}^{-1}$ (Beveridge, 1996). Karena itu, kegiatan budi daya yang dikembangkan tidak boleh mengakibatkan konsentrasi nutrien di perairan berada di atas level yang diperkenankan

Hasil perhitungan kapasitas asimilasi menunjukkan bahwa beban limbah yang masih diperkenankan dapat mencapai $6.762 \mathrm{~kg} \mathrm{~N}$ dan 3.077 $\mathrm{kg}$ P. Jika beban limbah untuk menghasilkan satu ton bandeng adalah $43,28 \mathrm{~kg} \mathrm{~N}$ dan $30,87 \mathrm{~kg} \mathrm{P}$ (Rachmansyah et al., 2003), maka kapasitas produksi yang diperkenankan masing-masing adalah 156 ton berdasarkan beban limbah $\mathrm{N}$ dan 100 ton berdasarkan beban limbah $\mathrm{P}$ (Tabel 3). 
Tabel 2. Produktivitas ikan dalam KJA di Teluk Awarange dan beberapa hasil penelitian lainnya

Table 2. Fish cage farming productivity in Awarange Bay and other research results

\begin{tabular}{|c|c|c|}
\hline $\begin{array}{l}\text { Produktivitas } \\
\text { Productivity }\end{array}$ & $\begin{array}{c}\text { Keterangan } \\
\text { Note }\end{array}$ & $\begin{array}{c}\text { Pustaka } \\
\text { References }\end{array}$ \\
\hline $110 \mathrm{t} \mathrm{km}^{-2}$ atau $1,1 \mathrm{t} \mathrm{ha}^{-1}$ & $\begin{array}{l}\text { Arus min } 5 \mathrm{~cm} \mathrm{~s}^{-1} \text {, kedalaman minimal kolom air di bawah } \\
\text { keramba } 4 \mathrm{~m} \text { (Minimum current velocity } 5 \mathrm{~cm} \mathrm{~s}-1 \text {, minimum } \\
\text { sitting depth of cage } 4 \mathrm{~m} \text { ) }\end{array}$ & Pilley (1992) \\
\hline $80-124 \mathrm{~kg} \mathrm{~m}^{-3}$ & 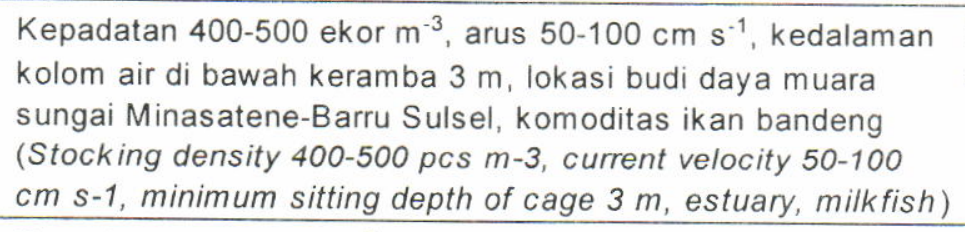 & $\begin{array}{l}\text { Burhanuddin et } \\
\text { al. (1994) }\end{array}$ \\
\hline $44,8 \mathrm{~kg} \mathrm{~m}^{-3}$ & $\begin{array}{l}\text { Kepadatan } 125 \text { ekor } \mathrm{m}^{-3} \text {, Arus } 0-11,3 \mathrm{~cm} \mathrm{~s}-1 \text {, kedalaman } \\
\text { kolom air bawah keramba } 15 \mathrm{~m} \text {, lokasi T. Labuange Barru } \\
\text { Sulsel, komoditas ikan bandeng (Stocking density } 125 \mathrm{pcs} \mathrm{m} \text { - } \\
\text { 3, Current velocity } 0-11.3 \mathrm{~cm} s-1 \text {, minimum sitting depth of } \\
\text { cage } 15 \mathrm{~m} \text {, Labuange Bay Barru, milkfish) }\end{array}$ & $\begin{array}{l}\text { Pongsapan } \\
\text { et al. (2001) }\end{array}$ \\
\hline $20 \mathrm{~kg} \mathrm{~m}^{-3}$ dan $100 \mathrm{~kg} \mathrm{~m}^{-3}$ & $\begin{array}{l}\text { Standar direkomendasikan tetapi tergantung pada kualitas air, } \\
\text { ukuran ikan, temperatur, pasokan } \mathrm{O}_{2} \text { (Recommended } \\
\text { standard but depend on water quality, fish size, temperature } \\
\text { and oxygen supply) }\end{array}$ & $\begin{array}{l}\text { Barker et al. } \\
(2002)\end{array}$ \\
\hline $42,1--86,8 \mathrm{~kg} \mathrm{~m}^{-3}$ & $\begin{array}{l}\text { Kepadatan } 150 \text { ekor } \mathrm{m}^{-3} \text {, arus } 0-10 \mathrm{~cm} \mathrm{~s}^{-1} \text {, kedalaman kolom } \\
\text { air di bawah KJA } 5 \mathrm{~m} \text {, lokasi T. Pegametan Bali, komoditas } \\
\text { ikan bandeng (Stocking density } 150 \text { pcs } \mathrm{m}-3 \text {, current velocity } \\
0-10 \mathrm{~cm} s-1 \text {, minimum sitting depth of cage } 5 \mathrm{~m} \text {, Pegametan } \\
\text { Bay Bali, milkfish) }\end{array}$ & $\begin{array}{l}\text { Rachmansyah } \\
\text { et al. (2002a) }\end{array}$ \\
\hline $\begin{array}{l}31,25 \mathrm{~kg} \mathrm{~m}^{-3} \text { atau } 1,28 \mathrm{t} \\
\mathrm{ha}^{-1}\end{array}$ & $\begin{array}{l}\text { Kepadatan } 62,5 \text { ekor } \mathrm{m}^{-3} \text {, arus } 0-10 \mathrm{~cm} \mathrm{~s}^{-1} \text {, kedalaman kolom } \\
\text { air di bawah keramba } 7 \mathrm{~m} \text {, lokasi budi daya teluk, komoditas } \\
\text { ikan bandeng (Stocking density } 62,5 \mathrm{pcs} \mathrm{m}-3 \text {, current velocity } \\
0--10 \mathrm{~cm} s-1 \text {, minimum sitting depth of cage } 7 \mathrm{~m} \text {, A warange } \\
\text { Bay Barru, milkfish) }\end{array}$ & $\begin{array}{l}\text { Penelitian ini } \\
\text { (This research) }\end{array}$ \\
\hline
\end{tabular}

Kapasitas asimilasi beban limbah yang diperoleh lebih ditujukan sebagai batasan maksimum beban limbah yang diperkenankan dan hanya mengacu pada batasan maksimum yang diperkenankan baik untuk $\mathrm{N}$ maupun $\mathrm{P}$. Penggunaan kapasitas asimilasi dalam menentukan daya dukung akan mengakibatkan overestimate disebabkan belum mempertimbangkan ketersediaan oksigen terlarut sebagai kebutuhan esensial bagi kehidupan ikan.

Tabel 3. Pendugaan beban limbah maksimum atau kapasitas produksi perairan Teluk Awarange, Barru Table 3. Assessment of maximum nutrient loading or production capacity of Awarange Bay, Barru

\begin{tabular}{|c|c|c|c|c|c|c|}
\hline $\begin{array}{l}\text { Nutrien } \\
\text { Nutrient }\end{array}$ & $\begin{array}{c}\text { Konsentrasi } \\
\text { yang } \\
\text { direkomendasik } \\
\text { an } \\
\text { Recommended } \\
\text { concentration } \\
\left(\mathrm{g} \mathrm{m}^{-3}\right)\end{array}$ & $\begin{array}{c}\text { Konsentrasi } \\
\text { dlm kondisi } \\
\text { steady state } \\
\text { Concentration } \\
\text { at the steady } \\
\text { state } \\
\left(\mathrm{g} \mathrm{m}^{3}\right)\end{array}$ & $\begin{array}{c}\text { Konsentrasi } \\
\text { yang masih } \\
\text { diperkenankan } \\
\text { Allowable } \\
\text { concentration } \\
\left(\mathrm{g} \mathrm{m}^{3}{ }^{3}\right)\end{array}$ & $\begin{array}{l}\text { Beban limbah } \\
\text { maksimum } \\
\text { yang masih } \\
\text { diperkenankan } \\
\text { Maximum } \\
\text { allowable of } \\
\text { nutrient load } \\
(\mathrm{kg})\end{array}$ & $\begin{array}{c}\text { Beban limbah } \\
\text { budi daya } \\
\text { bandeng } \\
\text { dalam KJA } \\
\text { Nutrient } \\
\text { loading from } \\
\text { milkfish cage } \\
\text { (kg t-1) }\end{array}$ & $\begin{array}{l}\text { Produksi yang } \\
\text { diperkenankan } \\
\text { Allowable } \\
\text { production } \\
\text { (ton) }\end{array}$ \\
\hline TN & 0.35 & 0.2252 & 0.1248 & 6.762 & 43.28 & 156 \\
\hline TP & 0.06 & 0.0032 & 0.0568 & 3.077 & 30.87 & 100 \\
\hline
\end{tabular}


Beban limbah pada kondisi daya dukung dapat mengakibatkan konsentrasi TN dan TP di perairan teluk masing-masing mencapai 0,2827 $\mathrm{mgN} \mathrm{L}^{-1}$ dan 0,0237 $\mathrm{mgP} \mathrm{L}^{-1}$ dengan rasio N:P adalah 11,9 (Tabel 4).

Rasio N:P dalam lingkungan perairan laut secara alami adalah antara 7:1 sampai 30:1 (SE, 2002). Pertumbuhan fitoplankton akan dipicu jika rasio N:P terlarut yang berasal dari budi daya mencapai $6: 1$ (Silvert \& Sowles, 1996). Rasio N:P perairan Teluk Awarange setelah memperoleh beban limbah pada level daya dukung adalah 11,9:1 (Tabel 4) berada pada rentang rasio yang dapat diterima, sehingga pada level beban limbah tersebut, kegiatan KJA bandeng tidak akan mempengaruhi perubahan rasio N:P dan masih dalam batas kapasitas asimilasi dari lingkungan perairan Teluk Awarange. Menurut Ryther (1981) dalam Folke et al. (1994), rasio N:P yang diperlukan untuk pertumbuhan tanaman di dalam lingkungan perairan yang tidak terpolusi adalah sekitar 7 dan ketidakseimbangan rasio N:P akan mengurangi jumlah jenis fitoplankton yang bermanfaat sebagai pakan untuk binatang yang filter-feeding. Perubahan rasio $N: P$ akan menyebabkan perkembangan sejumlah toxic alga bloom dari jenis yang berbeda. Pada umumnya blooming dari nitrogen-fixing blue green algae distimulasi oleh menurunnya rasio N/P dan meningkatnya rasio $\mathrm{N}: \mathrm{P}$ akan memicu produksi toksin dari jenis Chrysochromulina polypelis (Folke et al., 1994), melimpahnya spesies beracun seperti Alexandrium, Dinophysis, dan Pseudo-nitzschia (SE, 2002).

Komunitas fitoplankton di dalam ekosistem perairan dapat menjadi sensitif terhadap perubahan rasio N:P dan perubahan tersebut dapat dipicu oleh beban limbah yang masuk ke dalam perairan. Masukan nutrien ke dalam sistem perairan akan dimanfaatkan oleh fitoplankton dan kemampuan pemanfaatannya dipengaruhi oleh laju pelarutan (Gowen, 1994 dalam Black et al., 1997) dan waktu penyerapan nutrien yang dibutuhkan oleh fitoplankton. Jadi hanya di dalam perairan yang memiliki laju pelarutan yang relatif rendah yang akan memberikan kemampuan fitoplankton untuk memanfaatkan nutrien dan meningkatkan biomassanya (Black et al., 1997). Karena itu, pertumbuhan fitoplankton dan akumulasi biomassa di dalam perairan pesisir akan dikontrol oleh intensitas pencahayaan, laju pelarutan nutrien, dan intensitas pemangsa zooplankton. Sensitivitas perairan terhadap masukan nutrien tidak secara otomatis akan menimbulkan eutrofikasi yang memicu terjadinya blooming fitoplankton. Untuk mencegah terjadi eutrofikasi maka pendugaan kapasitas asimilasi terhadap beban limbah yang masuk ke dalam sistem perairan menjadi penting. Rasio N:P pada kondisi daya dukung adalah 11,9 sehingga dapat disimpulkan bahwa dalam kondisi beban limbah tidak melebihi kapasitas asimilasi, maka perairan Teluk Awarange akan tetap berada pada kondisi yang seimbang dan dinamis (steady state).

Daya dukung UPKB Teluk Awarange untuk pengembangan KJA bandeng sebanyak 36 ton dengan beban limbah masing-masing $1.558 \mathrm{~kg} \mathrm{~N}$ dan 1.111 $\mathrm{kg} \mathrm{P}$ atau sekitar $23 \%$ dari kapasitas asimilasi beban limbah $\mathrm{N}$ dan $76 \%$ dari kapasitas asimilasi beban limbah P. Dapat disimpulkan bahwa alokasi akuainput untuk KJA bandeng pada kondisi daya dukung 36 ton masih berada pada level yang aman bagi lingkungan perairan Teluk Awarange, karena kapasitas asimilasinya masih lebih besar dibandingkan dengan beban limbah KJA yang dihasilkan.

\section{Pendugaan Daya Dukung Melalui Pendekatan Keseimbangan Oksigen Terlarut}

Keseimbangan oksigen terlarut dalam perairan teluk dapat dijadikan acuan untuk verifikasi pendugaan daya dukung yang diperoleh. Keseimbangan oksigen terlarut ditentukan oleh ketersediaan oksigen teluk, kebutuhan konsumsi oksigen baik untuk biomassa ikan budi daya, BOD dan COD pada kondisi beban limbah sesuai daya dukung yang telah diperoleh sebesar 36 ton, serta batas minimum oksigen yang diperkenankan yaitu $4 \mathrm{mg} / \mathrm{L}$, maka performansi keseimbangan oksigen terlarut di perairan teluk adalah sebagai berikut:
(4) Ketersediaan DO teluk $=54.183 .600 \mathrm{~m}^{3} \times 6 \mathrm{mg} \mathrm{L}$ $1=325,012$ ton $\mathrm{O}_{2}$
(-) Nilai BOD dan COD dapat diestimasi menggunakan rasio yang dikemukakan oleh Diego-McGlone et

Tabel 4. Konsentrasi $\mathrm{N}$ dan $\mathrm{P}$ di perairan Teluk Awarange pada kondisi beban limbah daya dukung Table 4. Nitrogen and phosphor concentration of Awarange Bay at carriying capacity waste loading condition

\begin{tabular}{crrrrrr}
\hline $\begin{array}{c}\text { Nutrien } \\
\text { Nutrient }\end{array}$ & $\begin{array}{c}\text { Insitu } \\
\text { Insitu } \\
(\mathrm{kg})\end{array}$ & $\begin{array}{c}\text { KJA } \\
\text { Cage } \\
(\mathrm{kg})\end{array}$ & $\begin{array}{c}\text { Total } \\
\text { Total } \\
(\mathrm{kg})\end{array}$ & $\begin{array}{c}\text { Vol. Tlk } \\
\text { Water vol, of bay } \\
\left(\mathrm{m}^{3}\right)\end{array}$ & $\begin{array}{c}\text { Konst } \\
\text { Concentration } \\
(\mathrm{mg} \mathrm{L}-1)\end{array}$ & $\begin{array}{c}\text { N/P } \\
\text { Ratio }\end{array}$ \\
\hline $\mathrm{N}$ & 12,202 & 3,116 & 15,318 & $54,183,600$ & 0.2827 & 11.9 \\
$\mathrm{P}$ & 173 & 2,222 & 2,395 & $54,183,600$ & 0.0237 & \\
\hline
\end{tabular}


al. (2000) sebagai berikut: TN/BOD $=0,5$ dan COD/ $\mathrm{BOD}=2,6$; di mana $\mathrm{TN}$ pada kondisi setelah ada KJA. Dengan rasio tersebut maka $B O D=15,318 /$ $0,5 / 365=0,0839$ ton $\mathrm{O}_{2} / \mathrm{hr}$; sedangkan $\mathrm{COD}=$ $0,0839 \times 2,6=0,2181$ ton $\mathrm{O}_{2}$ per hari

• Kebutuhan oksigen ikan budi daya pada kondisi daya dukung $=36$ ton $\times 384,6 \mathrm{mg} \mathrm{kg}^{-1} \mathrm{jam}^{-1} \times 24$ jam $=0,332$ ton $\mathrm{O}_{2}$ per hari

- Ketersediaan DO teluk pada batas minimum DO $4 \mathrm{mg} / \mathrm{L}=54.183 .600 \mathrm{~m}^{3} \times 4 \mathrm{mg} \mathrm{L}^{-1}=216,734$ ton $\mathrm{O}_{2}$ per hari

Kebutuhan oksigen terlarut sebagian besar digunakan untuk budi daya ikan kemudian diikuti oleh COD dan BOD (Tabel 5). Jika batas minimum oksigen terlarut yang diperkenankan adalah $4 \mathrm{mg} \mathrm{L}^{-1}$ maka keseimbangan oksigen terlarut dalam perairan $T$. Awarange masih mengalami surplus sebesar 108,123 ton $\mathrm{O}_{2}$ dan UPKB sebesar 4,783 ton $\mathrm{O}_{2}$. Tentunya model keseimbangan $\mathrm{O}_{2}$ ini masih belum sempurna karena tidak mempertimbangkan pasokan $\mathrm{O}_{2}$ yang berasal dari difusi udara, proses fotosintesis, dan pasokan massa air pasang surut sehingga ketersediaan $\mathrm{O}_{2}$ teluk akan berfluktuasi dan kemungkinan lebih besar dari 325,012 ton $\mathrm{O}_{2}$. Namun paling tidak telah mempertimbangkan kebutuhan utama oksigen terlarut yang ada di dalam sistem perairan. Berdasarkan keseimbangan oksigen terlarut tersebut, maka batas daya dukung yang diperoleh sebesar 36 ton terbukti cukup realistis dan masih dapat didukung oleh keseimbangan oksigen terlarut dalam sistem perairan Teluk Awarange. Hal ini membuktikan bahwa pendekatan ketersediaan oksigen terlarut dalam menentukan daya dukung lebih realistis dan dapat dipertanggungjawabkan.

\section{Pendugaan Produksi Maksimum Tahunan}

Produksi maksimum tahunan bandeng KJA yang aman bagi lingkungan perairan T. Awarange adalah 90 ton per tahun atau 45 ton per musim pemeliharaan untuk UPKB seluas 28 ha. Hasil perhitungan ini belum memasukkan aspek ketersediaan oksigen terlarut yang merupakan kebutuhan esensial bagi kehidupan ikan budi daya. Jika dibandingkan dengan perhitungan daya dukung yang didasarkan atas kapasitas ketersediaan oksigen dan laju kebutuhan oksigen bandeng serta beban limbah $P$ baik dari KJA maupun non-KJA sebesar 36 ton dengan dua kali musim pemeliharaan per tahun, maka produksi tahunan mencapai 72 ton, masih di bawah nilai produksi maksimum tahunan yang aman yaitu 90 ton.

Pada kondisi daya dukung T. Awarange sebesar 36 ton ikan, maka dengan formula Silvert (1992) dapat diperoleh level kritis beban limbah organik (Ccrit) sebesar $32 \mathrm{mg} \mathrm{L}^{-1}$ jauh di bawah nilai TSS yang direkomendasikan aman untuk budi daya ikan secara intensif sebesar $80 \mathrm{mg} \mathrm{L}^{-1}$. Dengan demikian, penentuan daya dukung lingkungan perairan $\mathrm{T}$. Awarange sebesar 36 ton ikan, merupakan batasan yang mampu memberikan keberlanjutan manfaat bagi pengembangan budi daya ikan dalam KJA.

Daya dukung T. Awarange berdasarkan berbagai pendekatan diperoleh nilai antara 33-45 ton (Tabel 6). Jadi dapat disarankan bahwa penggunaan pendekatan ketersediaan oksigen terlarut dan laju komsumsi oksigen ikan akan menghasilkan nilai daya dukung yang cukup realistis. Namun nilai ini akan dipengaruhi oleh luasan dan kedalaman perairan yang ditetapkan layak untuk budi daya KJA, aspek

Tabel 5. Keseimbangan oksigen terlarut harian (ton $\mathrm{O}_{2}$ ) di perairan Teluk Awarange Table 5. Daily dissolved oxygen balance (ton $\mathrm{O}_{2}$ ) in Awarange Bay

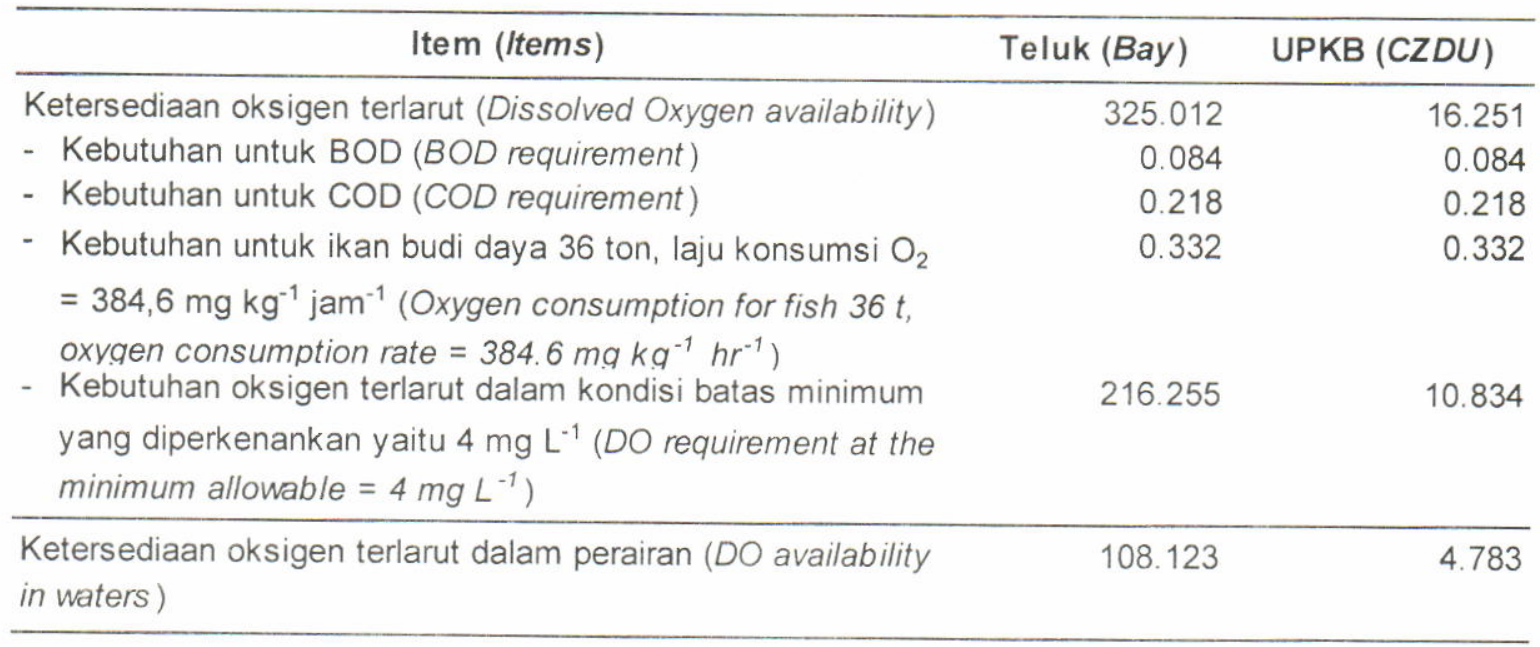

Keterangan: UPKB (Unit Pengembangan Kawasan Budi Daya)

Note: CZDU (Coastal Zone Development Unit) 
oseanografi dan karakteristik biofisik perairan. Secara umum model ini cenderung menghasilkan nilai yang konsisten dengan skema pengelolaan yang ada, tetapi pendekatan ini mendasarkan pada prinsip-prinsip ilmiah dan asumsi-asumsi yang lebih jelas terlihat.

\section{Pendugaan Kedalaman Minimal di Bawah Keramba}

Dengan formulasi Silvert (1992), maka untuk memproduksi ikan sebanyak 72 ton th ${ }^{-1}$ ( 2 kali musim tebar) diperlukan kedalaman minimum (Zmin) kolom air di bawah keramba adalah 4,4 meter. Pillay (1992) melaporkan bahwa berdasarkan karakteristik kedalaman dan laju pergantian air, maka peletakan keramba minimal di atas dasar perairan adalah $4 \mathrm{~m}$ untuk memastikan pelarutan dan distribusi limbah secara memadai. Jika kedalaman minimal 4,4 m yang diperoleh menjadi acuan volume air teluk (dengan luasan teluk pada kondisi MSL 564,41 ha) untuk pengenceran beban limbah TN dan TP pada kondisi beban limbah daya dukung, maka konsentrasi TN dan TP di perairan teluk masing-masing adalah 0,6168 mg $\mathrm{L}^{-1}$ dan $0,0964 \mathrm{mg} \mathrm{L}^{-1}$ (Tabel 7), lebih tinggi dari konsentrasi TN dan TP yang diperkenankan masing- masing adalah $0,350 \mathrm{mg} \mathrm{L}^{-1}$ dan $0,06 \mathrm{mg} \mathrm{L}^{-1}$. Kedalaman rataan lokasi budi daya adalah 9,7 m, sementara kedalaman efektif keramba $2 \mathrm{~m}$ dan kedalaman minimal di bawah keramba 4,4 m sehingga masih terdapat $3,3 \mathrm{~m}$ kedalaman kolom air yang mampu menetralisir beban limbah sehingga konsentrasi TN bisa turun mencapi $0,2798 \mathrm{mg} \mathrm{L}^{-1}$ dan TP $0,0437 \mathrm{mg} \mathrm{L}^{-1}$. Hubungan antara kedalaman kolom air di bawah $\mathrm{KJA}(X)$ dengan konsentrasi nutrient $(Y)$ digambarkan oleh regresi $(Y=1 /(0,3685 X-0,0002)$; $r$ $=0,99)$ untuk TN dan TP $(Y=1 /(-126,7920+$ $\left.117,3233 X^{0.1056} ; r=0,99\right)$. Berdasarkan regresi tersebut, maka konsentrasi TN dan TP yang diperkenankan masing-masing $0,350 \mathrm{mg} \mathrm{L}^{-1} \mathrm{TN}$ dan $0,06 \mathrm{mg} \mathrm{L}^{-1} \mathrm{TP}$ akan terjadi jika kolom air bawah KJA pada kedalaman masing-masing 7,7 m dan 6,7 m (Tabel 8)

Kedalaman minimum yang diperkenankan merupakan fungsi dari level produksi $Y$ dan kedalaman $Z$, artinya dengan meningkatkan produksi maka kebutuhan kolom air akan lebih dalam. Sementara tidal flushing ditentukan oleh kecepatan arus $\mathrm{V}$. Jadi kedalaman minimum kolom air di bawah keramba yang dipersyaratkan dapat mendukung beban limbah KJA pada kondisi daya dukung.

Tabel 6. Rekapitulasi daya dukung Teluk Awarange untuk KJA bandeng dengan berbagai pendekatan metode Table 6. Racapitulation of carrying capacity of Awarange Bay for milkfish cage farming with different approach methods

\section{Metode pendekatan (Approach methods)}

Ketersediaan $\mathrm{O}_{2}$ dan konsumsi oksigen pakan

Dissolved oxygen availability and food oxygen consumption

Ketersediaan $\mathrm{O}_{2}$ dan laju konsumsi $\mathrm{O}_{2}$ bandeng

Dissolved oxygen availability and oxygen consumption rate of milkfish

Beban limbah $P$

Loading $P$

Keseimbangan oksigen terlarut

Dissolved oxygen balance

Produksi maksimum tahunan mengacu beban limbah organik

Annual maximum production based on organic matter loading
Daya dukung Carrying capacity (ton)

Tabel 7. Konsentrasi TN dan TP di perairan Teluk Awarange pada kondisi beban limbah daya dukung dan kedalaman kolom air minimal di bawah keramba 4,4 m sebagai acuan volume air teluk

Table 7. Concentration of TN and TP in Awarange Bay at carrying capacity waste loading condition and minimum sitting depth of cage

\begin{tabular}{crrrccc}
\hline $\begin{array}{c}\text { Nutrien } \\
\text { (Nutrient) }\end{array}$ & $\begin{array}{c}\text { Insitu } \\
\text { Insitu } \\
\text { (ton) }\end{array}$ & $\begin{array}{c}\text { KJA } \\
\text { Cage } \\
\text { (ton) }\end{array}$ & $\begin{array}{c}\text { Total } \\
\text { Total } \\
\text { (ton) }\end{array}$ & $\begin{array}{c}\text { V. TIk } \\
\text { Water vol. of bay } \\
(\mathrm{m} 3)\end{array}$ & $\begin{array}{c}\text { Konst } \\
\text { Concentration } \\
\text { (mg/L) }\end{array}$ & $\begin{array}{c}\text { N/P } \\
\text { ratio }\end{array}$ \\
\hline N & 12,202 & 3,116 & 15,318 & $24,834,040$ & 0.6168 & 6.39 \\
P & 173 & 2,222 & 2,395 & $24,834,040$ & 0.0964 & \\
\hline
\end{tabular}


Tabel 8. Hubungan antara kedalaman kolom air di bawah KJA dengan konsentrasi TN dan TP Table 8. Relationship of the water depth under cage farming with concentration of TN and TP

\begin{tabular}{ccc}
\hline $\begin{array}{c}\text { Nutrien } \\
\text { (Nutrient) }\end{array}$ & $\begin{array}{c}\text { Konsentrasi yang } \\
\text { diperkenankan (Allowable } \\
\text { maximum concentration) } \\
\text { (mg L-1) }\end{array}$ & $\begin{array}{c}\text { Kedalaman minimal pada level } \\
\text { konsentrasi TN dan TP yang } \\
\text { diperkenankan (Minimum sitting depth } \\
\text { of cage at maximum concentration of }\end{array}$ \\
\hline N & 0.35 & $T N$ and TP) (m) \\
P & 0.06 & 7.7 \\
\hline
\end{tabular}

Perhitungan konsentrasi TN dan TP pada kolom air minimal di bawah KJA belum mempertimbangkan laju mineralisasi limbah, flushing rate dan dispersi horizontal limbah. Perhitungan hanya didasarkan atas asumsi bahwa limbah TN dan TP akan terlarut pada kolom air yang tersedia tidak melebihi konsentrasi yang diperkenankan sehingga dapat digunakan sebagai acuan posisi kedalaman minimal keramba dari dasar perairan. Karena itu, perlu pengembangan model hidrodinamika yang dapat menggambarkan dinamika nutrien di perairan sekitar KJA.

\section{Implikasi Daya Dukung terhadap Pengelolaan}

Tahapan awal yang sering dijumpai bagi pembudi daya KJA adalah sulitnya mendapatkan informasi tentang penetapan lokasi yang tepat, sementara pemilihan lokasi yang tepat merupakan langkah awal bagi penentu keberhasilan budi daya yang berkelanjutan. Informasi yang diperlukan pembudi daya dalam menetapkan lokasi KJA sering dan bahkan sulit diperoleh dari pihak berwenang yang diharapkan memiliki kapabilitas dan akses informasi tentang kondisi biofisik dan daya dukung dari lokasi yang tepat di wilayah kerjanya. Sementara pembudi daya juga dihadapkan pada masalah konflik kepentingan yang sulit diselesaikan dalam suatu kawasan pesisir. Kompleksitas masalah dalam pemilihan lokasi budi daya KJA akan dapat diminimasi jika penetapan ruang budi daya telah mendapat jaminan legalitas dan telah menjadi bagian dari sistem pengelolaan wilayah pesisir secara terpadu yang dapat memberikan akses informasi pembangunan perikanan budi daya

Kebutuhan informasi perikanan budi daya menyangkut distribusi spasial lokasi pengembangan budi daya yang dilengkapi dengan informasi daya dukung lingkungan perairan yang memuat data kapasitas produksi dari UPKB, maksimum jumlah rakit dan keramba yang diperkenankan, intensitas dan praktek-praktek budi daya yang sesuai standar operasional, kesepakatan jarak minimal antara unit budi daya, dan jumlah maksimum beban limbah budi daya yang diperkenankan serta kondisi biofisik dan kimia perairan sebagai rona lingkungan awal, berperan sangat penting dalam memformulasi kebijakan pengelolaan perikanan budi daya. Informasi tersebut sifatnya sangat spesifik untuk masing-masing kawasan pengembangan budi daya. Karena itu, hasil penelitian ini dapat menjadi sumber informasi yang diperlukan untuk kawasan pengembangan budi daya KJA serta panduan dalam perencanaan pengelolaan dan pengembangan budi daya KJA yang berkelanjutan

Informasi daya dukung yang diperoleh dari hasil penelitian ini baru menitikberatkan pada aspek yang terkait dengan kebutuhan oksigen untuk ikan budi daya, kapasitas asimilasi beban limbah budi daya, dan perkiraan kapasitas produksi maksimum tahunan. Terdapat sejumlah aspek penting (isu kritis) yang terkait dengan daya dukung lingkungan budi daya sebagai acuan dalam pengelolaan, regulasi dan lisensi usaha budi daya, di antaranya:

1. Model pendugaan daya dukung lingkungan perlu diintegrasikan dengan model hidrodinamika dan dispersi beban limbah. Karena itu, data dan informasi kondisi biofisik setiap UPKB menjadi penting untuk dilakukan

2. Dampak budi daya KJA yang terjadi di setiap UPKB adalah spesifik lokasi dan temporal sehingga membutuhkan tipe analisis yang berbeda.

3. Konsekuensi lingkungan akibat beban limbah budi daya dan dampaknya terhadap nutrifikasi dan proses lanjutan yang terkait dengan dinamika populasi plankton, proses degradasi limbah dan recovery sedimen sebagai penentu kapasitas asimilasi netto terhadap bentos dan penetapan level ambang kritis untuk pengkayaan nutrien, menjadi aspek yang perlu dikaji.

4. Meskipun teori ilmiah belum menjawab seluruh pertanyaan-pertanyaan yang terkait dengan daya dukung, namun pendekatan yang belum sempurna ini dapat menggarisbawahi bahwa asumsi-asumsi yang secara eksplisit digunakan, dapat memberikan alternatif pemecahan masalah dalam pengelolaan sumber daya perikanan budi daya 
dalam KJA di Teluk Awarange secara bertangung jawab.

\section{KESIMPULAN DAN SARAN}

Teluk Awarange dengan luas perairan mencapai 564,41 ha pada kondisi MSL memiliki UPKB yang layak untuk KJA seluas 28 ha atau hanya sekitar $5 \%$ dari total luas teluk dengan daya dukung sebesar 36 ton ikan budi daya. Dengan asumsi tingkat produktivitas keramba 0,25 ton/keramba, maka jumlah keramba berukuran $2 \times 2 \times 2,2 \mathrm{~m}^{3}$ yang dapat dioperasionalkan di perairan UPKB tersebut sebanyak 144 unit. Pola tebar dapat dilakukan sebanyak dua kali setahun untuk komoditas bandeng. Sedangkan kedalaman kolom air minimal di bawah keramba adalah $10 \mathrm{~m}$. Kapasitas asimilasi lingkungan perairan $\mathrm{T}$. Awarange mencapai 6,762 ton $\mathrm{N}$ dan 3,077 ton $\mathrm{P}$, dapat menerima beban limbah maksimum TN dan TP pada kondisi daya dukung 36 ton ikan dan masih berada di bawah batas yang diperkenankan masingmasing 0,35 $\mathrm{TN} \mathrm{mg} \mathrm{L}^{-1}$ dan 0,06 $\mathrm{TP}_{\mathrm{mg} \mathrm{L}} \mathrm{L}^{-1}$. Dengan demikian pengalokasian sumber daya perikanan budi daya sampai pada batas daya dukung masih dapat ditolerir oleh lingkungan perairan T. Awarange. Informasi yang diperoleh diharapkan menjadi acuan perencanaan dan regulasi UPKB di T. Awarange sehingga pengelola dapat mengalokasikan sumber daya perikanan budi daya sesuai daya dukung lingkungan.

\section{DAFTAR PUSTAKA}

Anonymous. 2002. Factors Related to the Sustainability of Shellfish Aquaculture Operations in the Firth of Thames. www.ew. govt.nz/ourenvironment/Coasts/ Coastalpressures/Marinefarming.htm [14 Agustus 2003].

Barg, U.C. 1992. Guidelines for the promotion of environmental management of coastal aquaculture development. FAO Fisheries Technical Paper 328, FAO, Rome, $122 \mathrm{pp}$.

Barker, D., G.L. Allan, S.J. Rowland, and J.M. Pickles. 2002. A Guide to Acceptable Procedures and Practices for Aquaculture and Fisheries Research. NSW Fisheries Animal Care and Ethics Committee. Port Stephens Fisheries Centre, Private bag 1, Nelson Bay NSW 2315, Australia, 52 pp.

Beveridge, M.C.M. 1984. Cage and pen farming: carrying capacity models and environmental impact. FAO Fish.Tech.Pap.255. FIRI/T255, 131 pp.

Beveridge, M.C.M. 1996. Cage Aquaculture. Second Edition. Fishing News Books, Ltd. Fornham Survey, England, $346 \mathrm{pp}$.

Black, E., R. Gowen, H. Rosenthal, E. Roth, D. Stechy, and F.J.R. Taylor. 1997. The costs of eutrophication from salmon farming: Implications for policy - A comment. Journal of Environmental Management, 50: 105-109.
Boyd, C.E. 1990. Water Quality in Ponds for Aquaculture. Alabama Agricultural Experiment Station, Auburn University, Alabama, $482 \mathrm{pp}$.

Burhanuddin, Sulaeman, dan S. Tonnek. 1994. Budidaya ikan bandeng (Chanos chanos Forskal) dalam keramba jaring apung volume kecil dengan padat penebaran berbeda. J. Penelitian Budidaya Pantai, 10(2): $57-70$.

Cholik, F., Rachmansyah, dan S. Tonnek, 1990. Pengaruh padat penebaran terhadap produksi nila merah, Oreochromis niloticus dalam keramba jaring apung di laut. J. Penelitian Budidaya Pantai, 6(2): 87-96.

Clark, J. 1974. Coastal Ecosystems: Ecological Considerations for Management of the Coastal Zone. The Conservation Foundation, Washington, D.C., $178 \mathrm{pp}$

Dahuri, R. 2002. The Application of Carrying Capacity Concept for Sustainable Coastal Resources Development in Indonesia. Center for Coastal and Marine Resources Studies (CCMRS) Bogor Agricultural University (IPB). www.pesisir.or.id/joumal/ Journal_Carrying\%20capacity.PDF. [September 2002]

Diego-McGlone, M.L., S. V. Smith, and V.F. Nicolas. 2000. Stochiometric interpretations of $\mathrm{C}: \mathrm{N}: \mathrm{P}$ ratios in organic waste materials. Marine Pollution Bulletin, 40(4): $325-330$

Folke, C., N. Kautsky, and M. Troell. 1994. The costs of eutrophication from salmon farming: Implications for policy. Journal of Environmental Management, 40: $173-182$

Gillibrand, P.A., M.J. Gubbins, C. Greathead, and I.M. Davies. 2002. Scottish Executive Locational Guidelines for Fish Farming: Predicted Levels of Nutrient Enhancement and Benthic Impact. Scottish Fisheries Research Report 63/2002. Aberdeen: Fisheries Research Services, $52 \mathrm{pp}$.

Jahnsen, TL. Regulation of Norwegian Aquaculture and Plans for the Future. www. mar.dfo-mpo.gc.ca/sciencel mesd/he/eim/report.htm/-63k [31 Januari 2002].

Kamaruddin dan Rachmansyah. 2003. Laju pengendapan feses bandeng, Chanos chanos dan pakan kerapu bebek Cromileptes altivelis. Laporan Hasil Penelitian. Balai Riset Perikanan Budidaya Air Payau, Maros, 8 pp.

Kenchington, R.A. and B.E.T. Huson. (Eds.) 1984. Coral Reef Management Handbook. Jakarta, indonesia. UNESCO Regional Officer for Science and Technology in South-East Asia, $281 \mathrm{pp}$

Lee, J.H., D.K. Choi, F. Arega, and B. Qu. 2001. Environmental management of mariculture in Hong Kong. Technical Report. Departemen of Civil Engineering. The University of Hong Kong. www. hku.hk/civil/enhydraulics/pdf/Ecs-Summary.pdf. [Nopember 2002].

McLean, W.E., J.O.T. Jensen, and D.F. Alderdice. 1993. Oxygen consumption rates and water flow requirements of Pacific salmon (Oncorhynchus spp.) in the fish culture environment. Aquaculture, 109: $281-313$. 
Meade, J.W. 1989. Aquaculture Management. An Avi Book, Van Nostrand Reinhold, 175 pp.

Pettigrew, N.R. Physical Processes in Blue Hill Bay and Net-Pen Aquaculture. School of Marine Sciences, University of Maine. www.fobhb.org/pettigrew.htm. [November 2002].

Pillay, T.V.R. 1992. Aquaculture and the Environment. Fishing News Books, Blackwell Sci. Publ. Ltd, 189 pp.

Pongsapan, D.S., Rachmansyah, dan A.G. Mangawe 2001. Pemanfaatan bahan baku lokal untuk formulasi pakan bandeng yang dipelihara dalam keramba jaring apung di laut. Laporan Hasil Penelitian. Balai Penelitian Perikanan Pantai, Maros, 12 pp.

Rachmansyah, T. Syarifuddin, dan T. Ahmad. 2002a. Pemanfaatan perairan pesisir bagi pengembangan budidaya bandeng dalam keramba jaring apung di Teluk Pegametan, Gondol, Bali. p: II.188-II.206. Dalam Bengen DG. et al. (Eds). Prosiding Konferensi Nasional III 2002 Pengelolaan Sumberdaya Pesisir dan Lautan Indonesia, Denpasar, 21-24 Mei 2002.

Rachmansyah, Tarunamulia, Usman, dan Makmur. 2002b. Karakteristik biofisik dan kelayakan bioteknis perairan Teluk Awarange bagi pengembangan budidaya bandeng dalam keramba jaring apung. Laporan Hasil Penelitian. Balai Riset Perikanan Budidaya Air Payau, Maros, 21 pp.

Rachmansyah, Usman, Makmur, dan Kamaruddin. 2002c. Laju pelarutan bahan organik, nitrogen dan phosphor pakan bandeng. Laporan Hasil Riset. Balai Riset Perikanan Budidaya Air Payau, Maros, 9 pp.

Rachmansyah, Usman, dan Makmur. 2002d. Laju konsumsi oksigen bandeng. Chanos chanos dan kerapu bebek, Cromileptes altivelis. Laporan Hasil Riset. Balai Riset Perikanan Budidaya Air Payau, Maros, $8 \mathrm{pp}$.

Rachmansyah dan Usman. 2003. Pendugaan beban limbah total nitrogen dan total fosfat yang masuk ke perairan Teluk Awarange. Laporan Hasil Penelitian. Balai Riset Perikanan Budidaya Air Payau, Maros, $11 \mathrm{pp}$.

Rachmansyah, Usman, dan D.S. Pongsapan. 2003. Pendugaan beban limbah budidaya bandeng dalam keramba jarring apung di laut. J. Pen. Per. Indonesia. 9(2): $65-76$.

(SE) Scottish Executive. 2002. Review and Synthesis of the Environmental Impacts of Aquaculture. Scottish Executive Central Research Unit. Edinburgh, 71 pp. www.scotland.gov.uk/cru/kd01/green/reia-10.asp [21 Februari 2003].

Schmittou, H.R. 1991. Cage Culture: A Method of Fish Production in Indonesia. FRDP, Central Research Institute for Fisheries, Jakarta, Indonesia.

Silvert, W. 1992. Assessing environmental impacts of finfish aquaculture in marine waters. Aquaculture, 107: $67-79$.

Silvert, W. and J.W. Sowles. 1996. Modelling environmental impacts of marine finfish aquaculture. J. Appl. Ichthyol.,12: 75-81.

Smith, V.H., G.D. Tilman, and J.C. Nekola. 1999. Eutrophication: impacts of excess nutrient inputs on freshwater, marine, and terrestrial ecosystems. Environmental Pollution, 100: 179-196.

Turner, G.E. 1988. Codes of practice and manual of procedures for consideration on introductions and transfer of marine and freshwater organisms, EIFAC/ CECPI, Occasional Paper No.23, 44 pp.

(UNEP) United Nations Environment Programme. 1993. Training Manual on Assessment of the Quantity and Type of Land-Based Pollution Discharges Into the Marine and Coastal Environment. RCU/EAS Technical Reports Series No.1.

Wedemeyer, G.A. 1996. Physiology of Fish in Intensive Culture Systems. Chapman \& Hall. New York, 232 $\mathrm{pp}$. 
